\title{
Of Fish and Things
}

\section{By DOROTHY T. HOFFOS, Rosetown, Sask.}

Illustrated by MOLLIE LAWRENCE, Regina

"Mom, what is an ichthyologist?" enquired my young son, spelling th word out slowly.

"An ichthyologist? Why, he's an itchy fisherman," I answered, with al the sang-froid I was capable of. And why not-I had been married to one fo twenty years! Although I actually have no aversion to ichthyology, which i merely a form of fish idolatry, neither am I an ichthyophile or lover of fist

Wordsworth wrote,

"The world is too much with us: late and soon,

Getting and spending, we lay waste our powers:

Little we see in nature that is ours."

These lines do not apply to my ichthyologist husband. He does not "lay wast his powers," but several times a year he likes to do what could be calle "communing" with nature. He agrees with Henry Thoreau, America's grea poet naturalist, who said in 1845 :

"In all nature quietude is essential to growth. Man must sneal into this life a few of the things we're planning for the nex This pilfering of a little joyous living will enrich our hearts.

To some twenty or thirty million fishermen throughout America-not that I said fishermen-this pilfering of a little "joyous living" merely mean "Let's go. fishing." Isaac Walton, British naturalist and author, expresse much the same thought in "The Compleat Angler" (1653) which was origin ally titled "Contemplative Man's Recreation."

Scientists tell us that man and the fishes both came originally out of th same slime. Although I sometimes doubt the wisdom of both in ever leavin it, I was a bit taken aback to discover that the earliest fish had as thei ancestors the lowly worms. Definitely, there is food for thought here-though based on scientific fact, too, because the above information was gleaned fror AMER CANA (topic; ichthyology, volume 14).

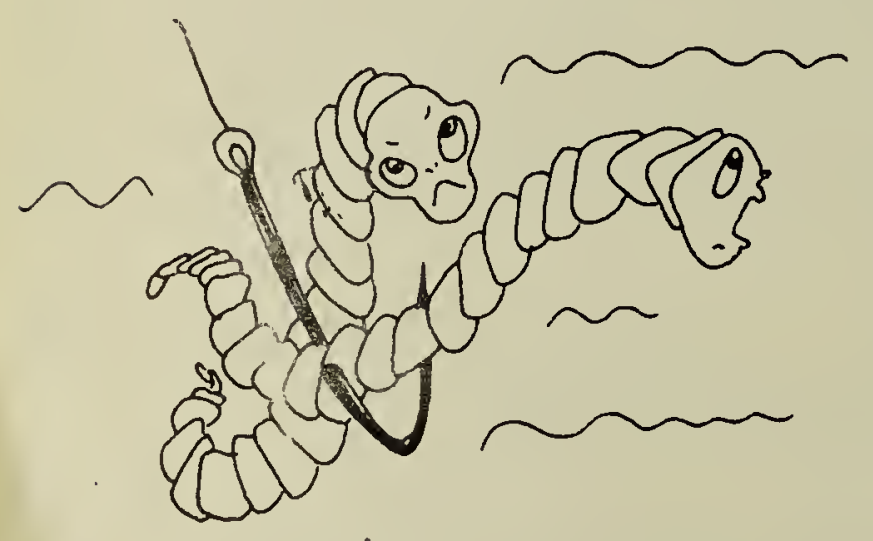

There was a time when worms playe a very important part in the life every fisherman. Many a fine fish ho been caught without the aid of artificis lure or spinning type of casting roc Although my husband blushes wit shame at the mere mention of it, can recall heavenly hours fishing wit an old willow pole, fine cord, cor from an old bottle, rusty old tin washe and a hook with a worm or grasshoppe impaled upon it! 'Tis true, it was years ago; the place was the old Saskat chewan River, and the inevitable catch was the lowly chub with the od gold-eye thrown in. Even though these are not the most fashionable fish an 


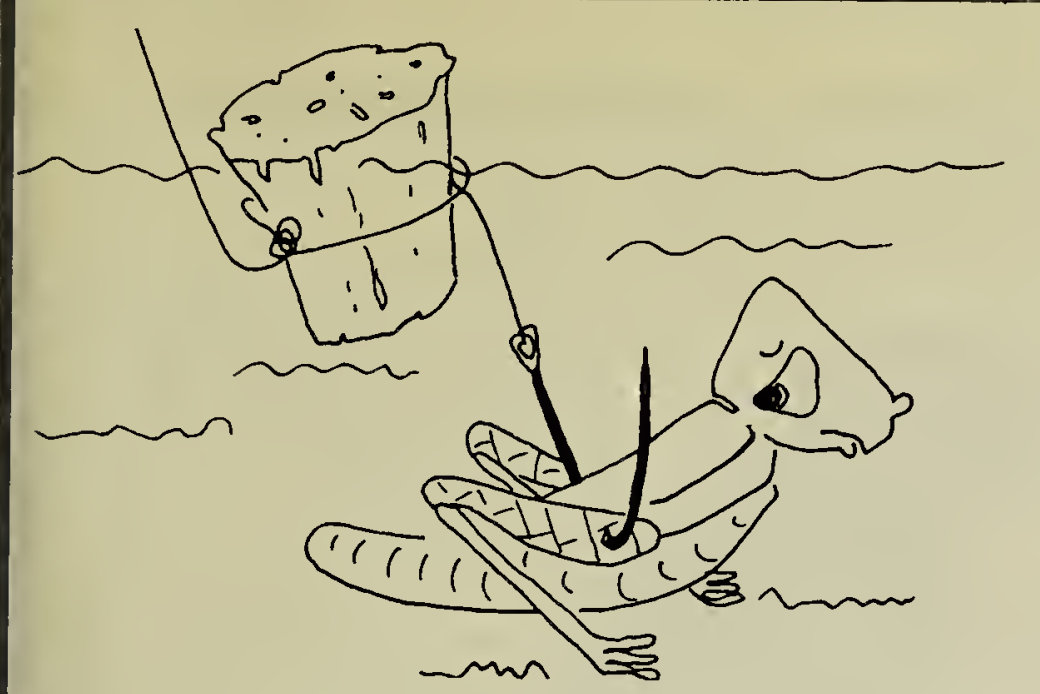

albeit they were not caught with the most expensive equipment, fried crisp and brown over a camp fire with a pot of scalding coffee they made a delectable dish!

Everyone enjoyed those fishing trips of the early years. While Father, never a loquacious man, mutely communed with the fishes, Mother snatch$\epsilon d$ a few precious hours of reading and the three young children, salt shakers in hand, tiptoed through the underbrush ready to catch bush rabbits by sprinkling salt on their tails.

However, the old order changed and the trek northward began. It has been exhilarating to explore the chains of untouched lakes hidden in forest of spruce and fir-inaccessible enough to become a challenge to modern man. Better yet, it has been good to discover that they abound in fish. The Department of Natural Resources Conservation Officers do not exaggerate about these watersthey are an ichthyologist's dream!

So far as the fisherman is concerned, spring begins when the fish rush madly up the rivers to spawn. Out come the fishing gear, the tents, the sleeping equipment, and the food supplies, and the trip northward begins. Babies may be born,

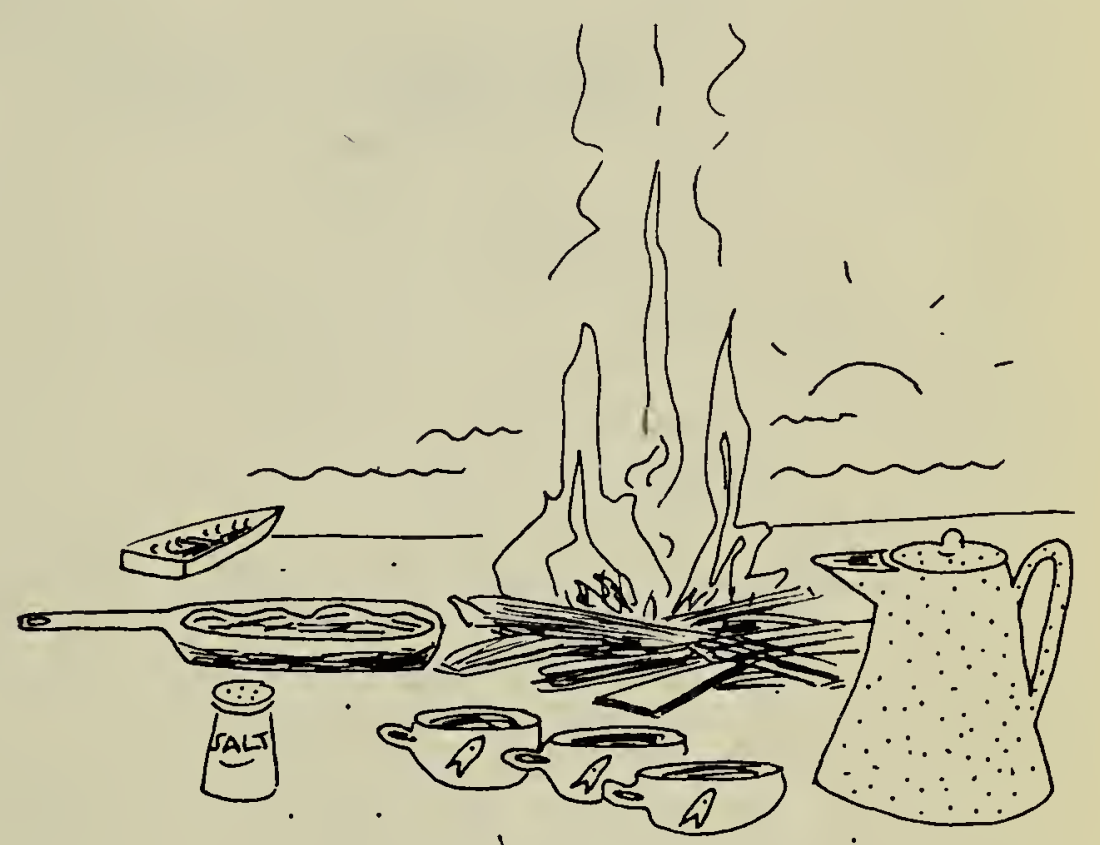
businesses may falter, but

nothing must interfere with this spring rendezvous.

Modern man, like his paleolithic ancestor, is out to conquer the wilderness and haul home his loot-pounds of it. He does, too, as all. prairie fishwives will tell you. He lays them at her feet, heads and innards intact, with the air of a conquering hero-and then hies himself off to bed! Is it acts like these that have caused the word "fishwife" to acquire such blatant meaning?

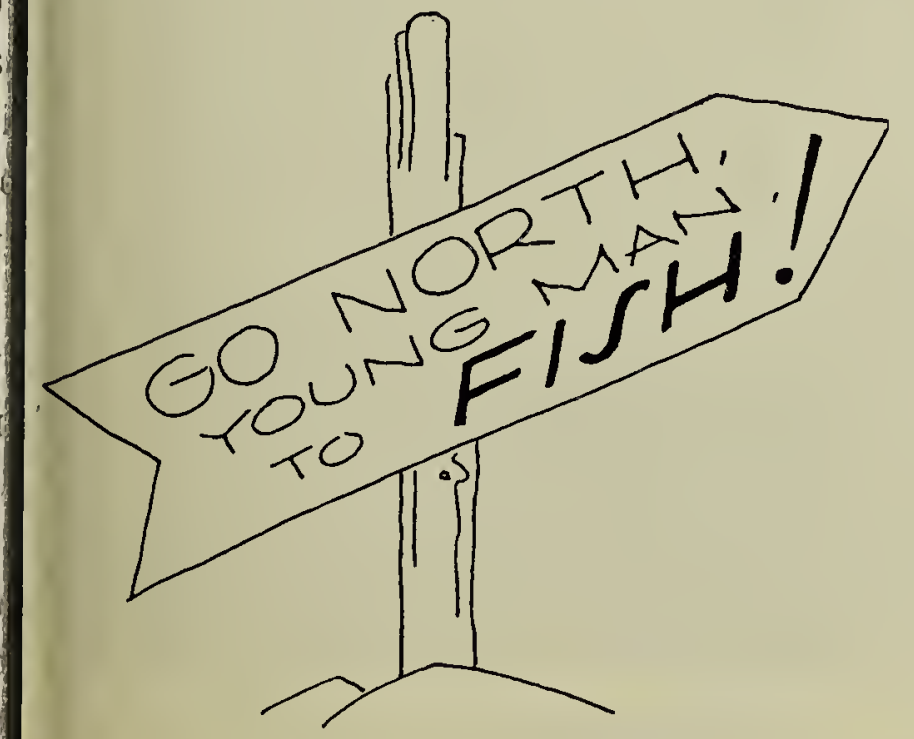

Although I have not gone fishing since my husband roared at me for feeding his minnow bait to the gulls, I still cling to my childhood love of sand, water, trees and birds. So, when I am privileged to accompany my husband on his fishing trips, I spend treasured joyous hours of living. I love the small northern Indian outposts where the native folk gather. I love sleeping in the great outdoors where the wind whispers softly or rushes with a mighty roar through the treetops. I love the sound of the water on the shore, the wild laughing cry of the loon. Here there is no cacophony. All nature seems in tune,

and all's right with my world. Would that it could remain so! 